Prepared in cooperation with the Town of Westerly, Rhode Island, and the Rhode Island Office of Housing and Community Development

\title{
Flood-Inundation Maps for the Lower Pawcatuck River in Westerly, Rhode Island, and Stonington and North Stonington, Connecticut
}

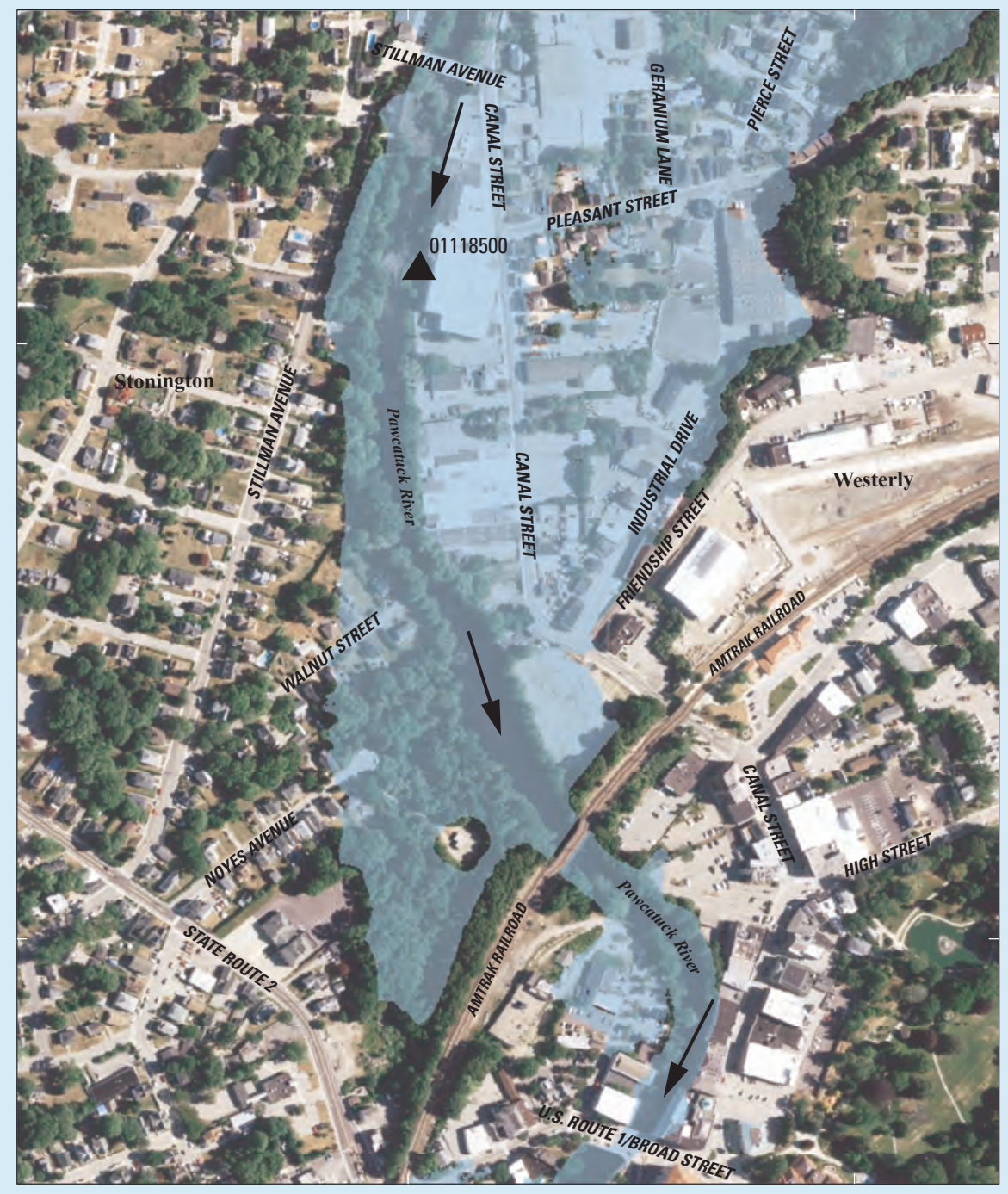

Scientific Investigations Report 2018-5112 
Cover. Flood-inundation map for a reach of the lower Pawcatuck River in Westerly, Rhode Island, and Stonington, Connecticut, corresponding to a stage of 15.0 feet, gage datum, approximately depicting the March 30, 2010, peak flood stage of 15.38 feet at the U.S. Geological Survey Pawcatuck River at Westerly, Rhode Island, streamgage 01118500. 


\section{Flood-Inundation Maps for the Lower Pawcatuck River in Westerly, Rhode Island, and Stonington and North Stonington, Connecticut}

By Gardner C. Bent and Pamela J. Lombard

Prepared in cooperation with the Town of Westerly, Rhode Island, and the Rhode Island Office of Housing and Community Development

Scientific Investigations Report 2018-5112 


\section{U.S. Department of the Interior \\ RYAN K. ZINKE, Secretary}

\section{U.S. Geological Survey James F. Reilly II, Director}

\section{U.S. Geological Survey, Reston, Virginia: 2018}

For more information on the USGS - the Federal source for science about the Earth, its natural and living resources, natural hazards, and the environment-visit https://www.usgs.gov or call 1-888-ASK-USGS.

For an overview of USGS information products, including maps, imagery, and publications, visit https://store.usgs.gov.

Any use of trade, firm, or product names is for descriptive purposes only and does not imply endorsement by the U.S. Government.

Although this information product, for the most part, is in the public domain, it also may contain copyrighted materials as noted in the text. Permission to reproduce copyrighted items must be secured from the copyright owner.

Suggested citation:

Bent, G.C., and Lombard, P.J., 2018, Flood-inundation maps for the lower Pawcatuck River in Westerly, Rhode Island, and Stonington and North Stonington, Connecticut: U.S. Geological Survey Scientific Investigations Report 20185112, 16 p., https://doi.org/10.3133/sir20185112.

ISSN 2328-0328 (online) 


\section{Acknowledgments}

The authors wish to thank the Rhode Island Water Resources Board for funding the operation and maintenance of the U.S. Geological Survey (USGS) streamgage at Pawcatuck River at Westerly, Rhode Island, 01118500, used for this study. Special thanks are given to the National Weather Service for providing forecasted river stages for the streamgage and for its continued support of the USGS flood-inundation mapping program. The authors thank the Federal Emergency Management Agency for providing the hydraulic model for an ongoing (2018) Risk Mapping, Assessment, and Planning program study for updating the Flood Insurance Studies for the Pawcatuck-Wood Watershed in Washington and Kent County, Rhode Island, and New London County, Connecticut. The authors also thank USGS field personnel for surveying hydraulic structures and cross sections on the Pawcatuck River during 2011, 2014-15, and August 2016, and USGS personnel for flood map preparation. 



\section{Contents}

Acknowledgments ……...................................................................................................................

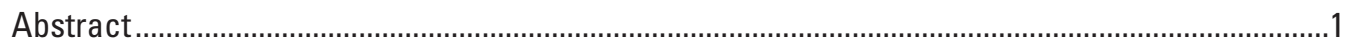

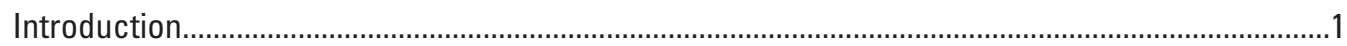

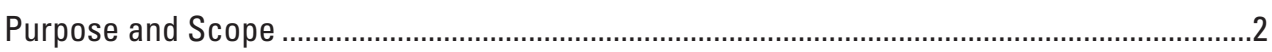

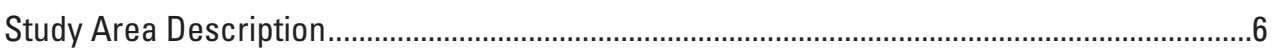

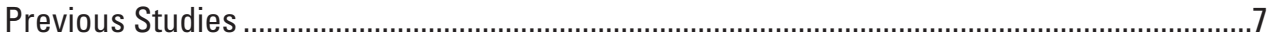

Creation of Flood-Inundation-Map Library ……..........................................................................

Computation of Water-Surface Profiles................................................................................

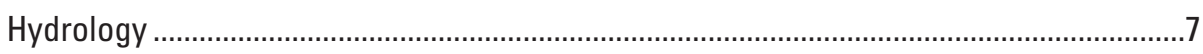

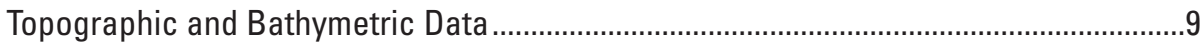

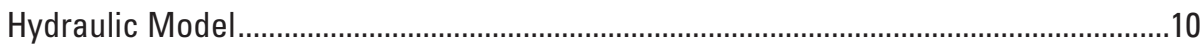

Development of Water-Surface Profiles ..........................................................................11

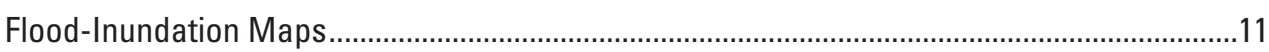

Flood-Inundation Map Delivery .......................................................................................12

Disclaimer for Flood-Inundation Maps .....................................................................13

Uncertainties and Limitations Regarding Use of Flood-Inundation Maps ......................13

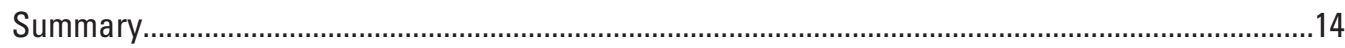

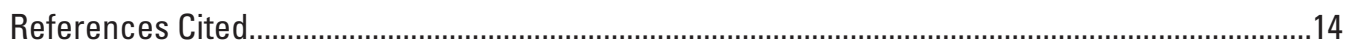

\section{Figures}

1. Map showing location of the lower Pawcatuck River study reach in Westerly, Rhode Island, and North Stonington and Stonington, Connecticut, and the U.S. Geological Survey Pawcatuck River at Westerly, Rhode Island, streamgage 01118500..3

2. Flood-inundation map for a reach of the lower Pawcatuck River in Westerly, Rhode Island, and Stonington, Connecticut, corresponding to a stage of 15.0 feet, gage datum, approximately depicting the March 30, 2010, peak flood stage of 15.38 feet at the U.S. Geological Pawcatuck River at Westerly, Rhode Island, streamgage 01118500

3. Graphs showing cumulative precipitation, stage, and streamflow data for the lower Pawcatuck River in southwestern Rhode Island and southeastern Connecticut during the floods of February 23 through April 5, 2010: A, cumulative daily precipitation at the National Weather Service climatological station at Westerly State Airport, Westerly, Rhode Island, $B$, stage, and $C$, streamflow at the U.S. Geological Survey Pawcatuck River at Westerly, Rhode Island, streamgage 01118500. Small rises and falls of stage and streamflow values for short periods ( 3 to 5 hours) are from tidal backwater effects

\section{Tables}

1. Description of U.S. Geological Survey Pawcatuck River at Westerly, Rhode Island, streamgage 01118500 .

2. Peak-discharge estimates for selected annual exceedance probabilities at the U.S. Geological Survey Pawcatuck River at Westerly, Rhode Island, streamgage 01118500, using annual peak discharges for water years 1928, 1936, and 1941-2016 ......8 
3. Estimated discharges for selected locations used in the hydraulic model of the lower Pawcatuck River in Westerly, Rhode Island, and Stonington and North Stonington, Connecticut, and the corresponding discharges, stages, and water-surface elevations at the U.S. Geological Survey Pawcatuck River at Westerly, Rhode Island, streamgage 01118500

4. Description of bridge crossings in the hydraulic model of the lower Pawcatuck River in Westerly, Rhode Island, and Stonington and North Stonington, Connecticut...10

5. Differences between 11 simulated water-surface elevations and stage elevations at 1 -foot intervals from 6.00 to 16.00 feet for the U.S. Geological Survey Pawcatuck River at Westerly, Rhode Island, streamgage 01118500.

6. Differences between the hydraulic model simulated water-surface elevations for the March 30, 2010, floodflows and the surveyed high-water mark elevations on the lower Pawcatuck River in Westerly, Rhode Island, and Stonington and North Stonington, Connecticut.

7. Stage, discharge, and approximate annual exceedance probability at the U.S. Geological Survey Pawcatuck River at Westerly, Rhode Island, streamgage 01118500 for profiles mapped on the lower Pawcatuck River in Westerly, Rhode Island, and Stonington and North Stonington, Connecticut. 


\section{Conversion Factors}

U.S. customary units to International System of Units

\begin{tabular}{lll}
\hline \multicolumn{1}{c}{ Multiply } & By & \multicolumn{1}{c}{ To obtain } \\
\hline inch (in.) & Length & \\
foot (ft) & 2.54 & centimeter $(\mathrm{cm})$ \\
mile (mi) & 0.3048 & meter $(\mathrm{m})$ \\
\hline \multicolumn{3}{c}{ Area } \\
\hline square mile $\left(\mathrm{mi}^{2}\right)$ & 1.609 & kilometer $(\mathrm{km})$ \\
\hline & 2.590 & square kilometer $\left(\mathrm{km}^{2}\right)$ \\
\hline cubic foot per second $\left(\mathrm{ft}^{3} / \mathrm{s}\right)$ & Flow rate & \\
\hline
\end{tabular}

\section{Datum}

Vertical coordinate information is referenced to either stage (the height above an arbitrary datum established at a streamgage) or to the North American Vertical Datum of 1988 (NAVD 88).

Horizontal coordinate information is referenced to the North American Datum of 1983 (NAD 83).

Elevation, as used in this report, refers to distance above the vertical datum.

\section{Abbreviations}
AEP annual exceedance probability
AHPS Advanced Hydrologic Prediction Service
DEM digital elevation model
DGPS differential global positioning system
FEMA Federal Emergency Management Agency
FIS Flood Insurance Study
GIS geographic information system
HWM high-water mark
lidar light detection and ranging
NGS National Geodetic Survey
NWIS National Water Information System
NWS National Weather Service
RTK real-time kinematic
USGS U.S. Geological Survey 



\title{
Flood-Inundation Maps for the Lower Pawcatuck River in Westerly, Rhode Island, and Stonington and North Stonington, Connecticut
}

\author{
By Gardner C. Bent and Pamela J. Lombard
}

\section{Abstract}

A series of 11 digital flood-inundation maps was developed for a 5.5-mile reach of the lower Pawcatuck River in Westerly, Rhode Island, and Stonington and North Stonington, Connecticut, by the U.S. Geological Survey (USGS) in cooperation with the Town of Westerly, Rhode Island, and the Rhode Island Office of Housing and Community Development. The coverage of the maps extends from downstream from the Ashaway River inflow at the State Border between Hopkinton and Westerly, Rhode Island, and North Stonington, Connecticut, to about 500 feet (ft) downstream from the U.S. Route 1/Broad Street bridge on the State border between Westerly, Rhode Island, and Stonington, Connecticut. A onedimensional step-backwater hydraulic model created and calibrated for an ongoing (2018) Federal Emergency Management Agency Flood-Insurance Study for New London County, Connecticut and Washington County, Rhode Island was updated for this study. The hydraulic model reflects the removal of the White Rock dam during 2015-16, and was calibrated using the stage-discharge relation at the USGS Pawcatuck River at Westerly, Rhode Island, streamgage (01118500) and documented high-water marks from the March 30, 2010, flood, which had a peak flow slightly greater than the estimated 0.2-percent annual exceedance probability floodflow.

The hydraulic model was used to compute water-surface profiles for 11 flood stages at 1-ft intervals referenced to the USGS Pawcatuck River at Westerly, Rhode Island, streamgage (01118500) and ranging from $6.0 \mathrm{ft}(3.32 \mathrm{ft}$, North American Vertical Datum of 1988), which is the National Weather Service Advanced Hydrologic Prediction Service flood category "action stage," to $16.0 \mathrm{ft}$ (13.32 ft, North American Vertical Datum of 1988), which is the maximum stage of the stage-discharge relation at the streamgage and exceeds the National Weather Service Advanced Hydrologic Prediction Service flood category "major flood stage" of $11.0 \mathrm{ft}$. The simulated water-surface profiles were combined with a geographic information system digital elevation model derived from light detection and ranging (lidar) data with a $1.0-\mathrm{ft}$ vertical accuracy to create flood-inundation maps. The flood-inundation maps depict estimates of the areal extent and depth of flooding corresponding to 11 selected flood stages at the streamgage. The flood-inundation maps depict only riverine flooding and do not depict any tidal backwater or coastal storm surge that could occur in the lower part of the river reach. The flood-inundation maps can be accessed through the USGS Flood Inundation Mapping Science website at https://water.usgs.gov/osw/flood_inundation. Near-realtime stages and discharges at the Pawcatuck River streamgage can be obtained from the USGS National Water Information System at https://waterdata.usgs.gov/. The National Weather Service Advanced Hydrologic Prediction Service provides flood forecast of stage for this site (WSTR1) at https://water.weather.gov/ahps/.

The availability of flood-inundation maps referenced to current and forecasted water levels at the USGS Pawcatuck River at Westerly, Rhode Island streamgage (01118500) can provide emergency management personnel and residents with information that is critical for flood response activities such as evacuations and road closures, and postflood recovery efforts. The flood-inundation maps are nonregulatory but provide Federal, State, and local agencies and the public with estimates of the potential extent of flooding during flood events.

\section{Introduction}

During late February through early April of 2010, the State of Rhode Island, and the Pawcatuck River Basin (Pawcatuck-Wood Watershed) in southwestern R.I. and southeastern Connecticut experienced the most substantial flooding in 200 years, with damages estimated in the hundreds of millions of dollars, and the entire State was included in the President's emergency declaration (EM-3311) on March 30, 2010 (Zarriello and others, 2014). Flooding along the lower part of the Pawcatuck River resulted in the closure of the Stillman Avenue and U.S. Route 1/ Broad Street bridges along the Westerly, Rhode Island (R.I.), and Stonington, Connecticut (Conn.), 
border (fig. 1). Although the Stillman Avenue and U.S. Route 1/Broad Street bridges were not overtopped, the flood waters reached the side of the bridge decks, which resulted in bridge closures. The U.S. Route 1/Broad Street bridge was closed for about 2 weeks until it was deemed safe for traffic (Hallenbeck, 2010). The flooding also affected a power substation and damaged numerous businesses and private homes on Canal Street, Industrial Drive, Pleasant Street, and Pierce Street in Westerly, R.I. (fig. 2).

Four precipitation events occurred from February 23 through March 30, 2010, totaling 17.24 inches (fig. 3A) at Westerly State Airport, Westerly, R.I. (Global Historical Climatology Network-Daily station number: USW00014794; National Oceanic and Atmospheric Administration, 2010; station is not shown on map and is located about 2.4 miles [mi] southeast of the U.S. Route 1/Broad Street bridge in Westerly, R.I., and Stonington, Conn.). Rainfall from each of the four precipitation events was from about 2.9 to 6.4 inches, resulting in a series of four flood events. The final flood event on March 30, 2010, culminated with a new peak stage and flow of record at the U.S. Geological Survey (USGS) streamgage on the Pawcatuck River at Westerly, R.I. (01118500; hereafter referred to as the Pawcatuck River at Westerly streamgage; fig. 1), on March 30, 2010 (fig. 3B and 3C; U.S. Geological Survey, 2017). The new peak of record has a stage of 15.38 feet (ft) and discharge of 10,800 cubic feet per second ( $\mathrm{ft}^{3} / \mathrm{s}$ ) (table 1). The stage was about $2.5 \mathrm{ft}$ higher and the discharge about 1.5 times greater than the previous peak of record (the previous peak stage was $12.86 \mathrm{ft}$ and discharge was $7,070 \mathrm{ft}^{3} / \mathrm{s}$ on June 6, 1982 for water years 1941-200911). The March 30, 2010 peak flow of $10,800 \mathrm{ft}^{3} / \mathrm{s}$ was slightly greater than the estimated 0.2 -percent annual exceedance probability floodflow (table 7 of Zarriello and others, 2012).

Prior to this study, emergency responders in the municipalities of Westerly, R.I., and Stonington and North Stonington, Conn., relied on four information sources to make decisions on how to best alert the public and mitigate flood damages during floods. Two of these sources are the Federal Emergency Management Agency (FEMA) Flood Insurance Studies (FISs), for New London County, Conn., and Washington County, R.I. (Federal Emergency Management Agency, 2013a and 2013b, respectively). The third source of information is the Pawcatuck River at Westerly streamgage, about $500 \mathrm{ft}$ downstream from the Stillman Avenue bridge, which provides stage and discharge data from November 1940 to the present (2018) and annual peak flow data from water years 1928, 1936, and 1941 to the present (2018) (U.S. Geological Survey, 2017). The fourth source of flood-related information is the National Weather Service (NWS) Advanced Hydrologic Prediction Service (AHPS), which issues flood forecasts of stage for the Pawcatuck River at Westerly streamgage (WSTR1; National Weather Service, 2017).

${ }^{1} \mathrm{~A}$ water year is the 12 -month period from October 1 through September 30 of the next year and is designated by the calendar year in which it ends.
Although the current stage at a USGS streamgage is particularly useful for residents in the immediate vicinity of a streamgage, it is of limited use to residents farther upstream or downstream because the water-surface elevation is not constant along the entire stream reach. Knowledge of a water level at a streamgage is difficult to translate into depth and areal extent of flooding at points distant from the streamgage. One way to address these informational gaps is to produce a library of flood-inundation maps that are referenced to the stages recorded at a USGS streamgage. By referring to the appropriate map, emergency responders can discern the severity of flooding (depth of water and areal extent), identify roads that are or may soon be flooded, and make plans for notification or evacuation of residents in harm's way for some distance upstream and downstream from the streamgage. In addition, the capability to visualize the potential extent of flooding has been shown to motivate residents to take precautions and heed warnings that they previously might have disregarded. In 2016-18, the USGS, in cooperation with the Town of Westerly, R.I., and the Rhode Island Office of Housing and Community Development, conducted a project to produce a library of flood-inundation maps for the lower Pawcatuck River in Westerly, R.I., and North Stonington and Stonington, Conn., using a hydraulic model.

\section{Purpose and Scope}

This report describes the development of a hydraulic model and creation of a series of 11 flood-inundation maps for a 5.5-mi reach of the lower Pawcatuck River from downstream from the Ashaway River inflow to about $500 \mathrm{ft}$ downstream from the U.S. Route 1/Broad Street bridge (fig. 1) in Westerly, R.I., and North Stonington and Stonington, Conn. The maps, in 1-ft increments, cover a range in stage from 6.0 to $16.0 \mathrm{ft}$ (gage datum) at the Pawcatuck River at Westerly streamgage. The range of stage shown on the maps is from $6.0 \mathrm{ft}$, which is the NWS AHPS flood category "action stage," to $16.0 \mathrm{ft}$, which is the maximum stage of the stage-discharge relation at the streamgage and exceeds the maximum recorded peak stage (15.38 ft on March 30, 2010). The flood-inundation maps depict only riverine flooding and do not depict any tidal backwater or coastal storm surge that could occur in the lower part of the river reach. The flood-inundation maps were developed for display on the USGS Flood Inundation Mapper website (http://wimcloud.usgs.gov/apps/FIM/FloodInundationMapper. html). The maps will help to guide the general public in taking individual safety precautions and will provide emergency management personnel with a tool to efficiently manage emergency flood operations and postflood recovery efforts. The flood-inundation maps are nonregulatory but provide Federal, State, and local agencies and the public with estimates of the potential extent of flooding during flood events. 


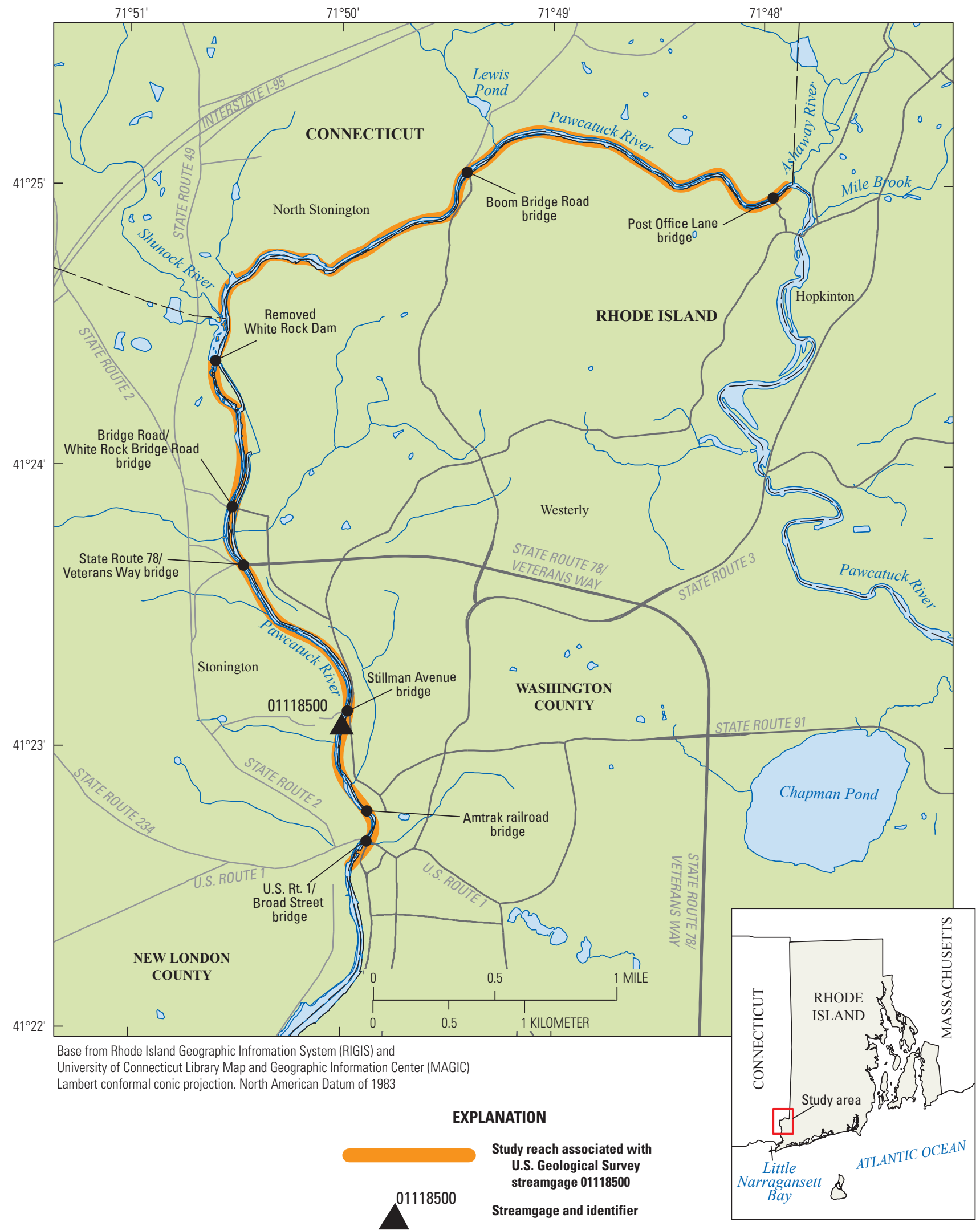

Figure 1. Location of the lower Pawcatuck River study reach in Westerly, Rhode Island, and North Stonington and Stonington, Connecticut, and the U.S. Geological Survey Pawcatuck River at Westerly, Rhode Island, streamgage 01118500. 


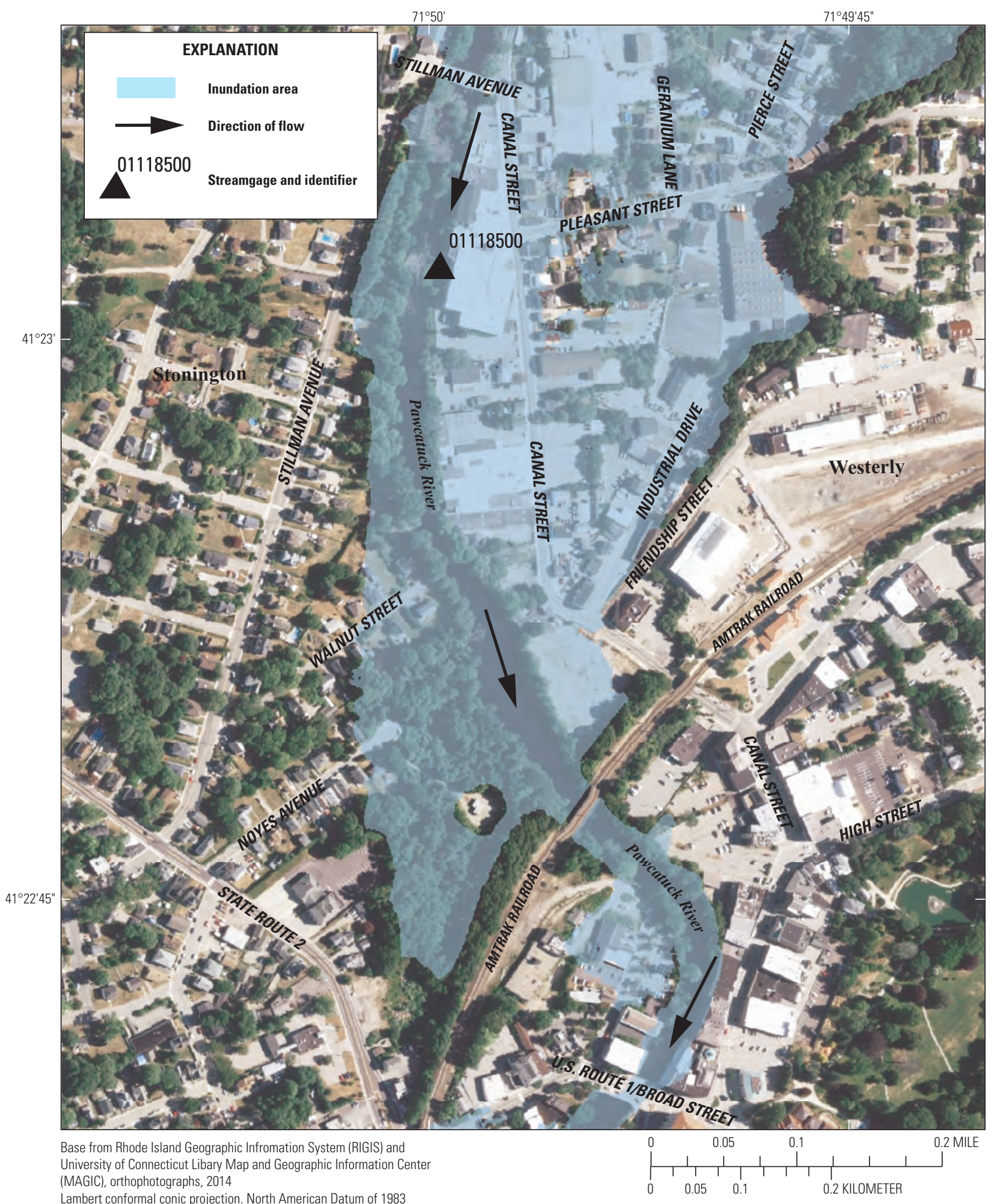

Figure 2. Flood-inundation map for a reach of the lower Pawcatuck River in Westerly, Rhode Island, and Stonington, Connecticut, corresponding to a stage of 15.0 feet, gage datum, approximately depicting the March 30, 2010, peak flood stage of 15.38 feet at the U.S. Geological Pawcatuck River at Westerly, Rhode Island, streamgage 01118500 . Gage datum of 15.0 feet corresponds to 12.32 feet, North American Vertical Datum of 1988. (The Pawcatuck River is the border between Westerly, Rhode Island, and Stonington, Connecticut.) 



Figure 3. Cumulative precipitation, stage, and streamflow data for the lower Pawcatuck River in southwestern Rhode Island and southeastern Connecticut during the floods of February 23 through April 5 , 2010: $A$, cumulative daily precipitation at the National Weather Service climatological station at Westerly State Airport, Westerly, Rhode Island, $B$, stage, and $C$, streamflow at the U.S. Geological Survey Pawcatuck River at Westerly, Rhode Island, streamgage 01118500. Small rises and falls of stage and streamflow values for short periods ( 3 to 5 hours) are from tidal backwater effects. NWS, National Weather Service; AHPS, Advanced Hydrologic Prediction Service; ft, foot. 
Table 1. Description of U.S. Geological Survey Pawcatuck River at Westerly, Rhode Island, streamgage 01118500.

[Streamgage location is shown in figure 1. USGS, U.S. Geological Survey; NAD 83, North American Datum of 1983; NAVD 88, North American Vertical Datum of 1988; $\mathrm{mi}^{2}$, square mile; $\mathrm{ft}$, foot; $\mathrm{ft}^{3} / \mathrm{s}$, cubic foot per second]

\begin{tabular}{ll}
\hline & \multicolumn{1}{c}{ Site information } \\
\hline USGS streamgage name & Pawcatuck River at Westerly, Rhode Island \\
USGS streamgage number & 01118500 \\
Drainage area & $295 \mathrm{mi}^{2}$ \\
Latitude (decimal degrees, NAD 83) & 41.38371 \\
Longitude (decimal degrees, NAD 83) & -71.83312 \\
Period of peak-flow record, in water years ${ }^{1}$ & 1928,1936, and 1941 to present \\
Maximum stage (gage datum [elevation, above NAVD 88]); date & $15.38 \mathrm{ft}[12.70 \mathrm{ft}]$; March 30, 2010 \\
Maximum discharge; date & $10,800 \mathrm{ft} 3$ s; March 30, 2010 \\
\hline
\end{tabular}

${ }^{1} \mathrm{~A}$ water year is the 12 -month period from October 1 of one year through September 30 of the following year and is designated by the calendar year in which it ends.

\section{Study Area Description}

The Pawcatuck River Basin (not shown in fig. 1) covers an area of about 300 square miles $\left(\mathrm{mi}^{2}\right)$ in southern Rhode Island and southeastern Connecticut that discharges into Little Narragansett Bay and the Atlantic Ocean on the border between the States. The Pawcatuck River Basin lies within three counties-Washington and Kent Counties, R.I., and New London County, Conn. (not shown in fig. 1). The Pawcatuck River begins at the outflow of Worden Pond (not shown in fig. 1) in southern Rhode Island and flows generally westward until its flow turns southward and discharges into Little Narragansett Bay. The Pawcatuck River is a low-gradient river that flows about $29 \mathrm{mi}$ through rural areas of Rhode Island until it reaches Westerly, R.I., and Stonington, Conn., where it has some commercial and industrial land uses and medium to high density residential housing. The lower Pawcatuck River towns of Westerly, Stonington, and North Stonington had populations of 22,787; 18,545 ; and 5,297; respectively, in 2010 (U.S. Census Bureau, 2016).

The upstream end of the study reach for the lower Pawcatuck River starts at the Ashaway River inflow on the Hopkinton and Westerly, R.I., and North Stonington, Conn., town and State boundaries (fig. 1) and has a drainage area of $271 \mathrm{mi}^{2}$. The 5.5-mi study reach has several small unnamed tributaries (drainage areas less than about $1.0 \mathrm{mi}^{2}$ ) and one named tributary-Shunock River in North Stonington (16.5- $\mathrm{mi}^{2}$ drainage area). The downstream end of the study reach is about $500 \mathrm{ft}$ downstream from the U.S. Route 1/Broad Street bridge and has a drainage area of $296 \mathrm{mi}^{2}$. The Pawcatuck River at Westerly streamgage (01118500) is located $0.6 \mathrm{mi}$ upstream from the downstream end of the study reach and $4.9 \mathrm{mi}$ downstream from the upstream end of the study reach (downstream from the Ashaway River inflow; fig. 1). The streamgage is associated with a drainage area of $295 \mathrm{mi}^{2}$. The study reach is crossed by five road bridges (the Boom Bridge Road bridge is currently [2018] inactive), one railroad bridge, and one wooden farm bridge (Post Office Lane). The White Rock dam, about 0.6 mi upstream from Bridge Road/White Rock Bridge Road bridge and near the middle of the study reach, was removed in 2015-16 (fig. 1).

The water-surface elevations of the most downstream section (about $0.7 \mathrm{mi}$ ) of the lower Pawcatuck River study reach (from about Stillman Avenue bridge to the end of the reach about $500 \mathrm{ft}$ downstream from the U.S. Route 1/Broad Street bridge [fig. 1]) could be affected by tidal backwater from high tides. Stage data at the Pawcatuck at Westerly streamgage (U.S. Geological Survey, 2017) generally show only a rise (tidal backwater effect) of a few tenths of a foot in stage for 3 to 5 hours around high tides during a full or new moon phase for stages greater than $6 \mathrm{ft}$. For stages greater than $6 \mathrm{ft}$ at the streamgage during first or last quarter moon phases, there is no clear rise in the stage due to tidal backwater. Several field observations at the downstream end of the study reach (about $500 \mathrm{ft}$ downstream from the U.S. Route 1/ Broad Street bridge) showed that tidal backwater can cause a rise of up to about 2 to $4 \mathrm{ft}$ in stage around high tides during a full or new moon phase for stages less than about $6 \mathrm{ft}$ at the Pawcatuck at Westerly streamgage (Andrew Massey, U.S. Geological Survey, oral commun., 2016). Additionally, stages generally rise less than about $1 \mathrm{ft}$ because of tidal backwater in this downstream end of the study reach during the first and last quarter moon phases with stages greater than about $6 \mathrm{ft}$ at the Pawcatuck at Westerly streamgage. For stages from 6 to $16 \mathrm{ft}$ (floodflows) at the Pawcatuck River at Westerly streamgage, the effect of tidal backwater for 3 to 5 hours around high tides during a full or new moon is generally only a few tenths of a foot (U.S. Geological Survey, 2017). For example, during the late February through early April 2010 floods, the Pawcatuck River at Westerly streamgage showed from about 0.1 to $0.5 \mathrm{ft}$ 
of tidal backwater during high tides within a few days of the new moon on March 15, 2010, and full moons on February 28 and March 29, 2010 (fig. 3B). However, in the days around the new moon on March 15, 2010, with river stages ranging from about 6 to $9 \mathrm{ft}$, the tidal backwater was only about 0.10 to $0.15 \mathrm{ft}$. During the days around the full moon on March 29, 2010, during which river stages ranged from about 7 to $15 \mathrm{ft}$, the tidal backwater was not identifiable. Thus, there is likely a minimal effect of tidal backwater on the flood-inundation maps for stages from 6 to $16 \mathrm{ft}$.

The FEMA FISs for New London and Washington Counties (Federal Emergency Management Agency, 2013b and 2013a, respectively) depict tidal backwater for the 1-percent annual exceedance probability (AEP) water-surface elevation extending upstream to midway between the Stillman Avenue and State Route 78 bridges. A study by the Rhode Island Coastal Resources Management Council (2017) depicted tidal surges from the Hurricane of 1938 and Hurricane Carol (1954) extending up the Pawcatuck River to just downstream from the former White Rock dam (Hurricane of 1938) and to midway between the State Route 78 and Bridge Road/White Rock Bridge Road bridges (Hurricane Carol). The study also depicted the tidal surges of Hurricanes Bob (1991) and Sandy (2012) extending up the Pawcatuck River to midway between Stillman Avenue and State Route 78 bridges. The effects of tidal backwater and storm surge on water-surface elevations were beyond the scope of this project, so the flood-inundation maps associated with this project depict only riverine flooding and do not account for (nor depict) any inundation that could result from possible tidal backwater or coastal storm surge in the lower part of the river reach.

\section{Previous Studies}

Several flood-related studies of the lower Pawcatuck River were done by the USGS after the late February through early April 2010 floods in Rhode Island. Thirty-nine highwater marks (HWMs) were flagged and surveyed along the main stem of the Pawcatuck River-10 of which are in the lower Pawcatuck River study reach - following the floods (table 1 of Zarriello and Bent, 2011). The magnitudes of floodflows for selected AEPs at the Pawcatuck River at Westerly streamgage were calculated by using annual peak flow data for water years 1928, 1936, and 1941 through 2010 (table 13 of Zarriello and others, 2012) but were updated for this study with annual peak flow data through water year 2016 (table 2) using the methods described in England and others (2018). The USGS developed a hydraulic model for the Pawcatuck River in 2014 (Zarriello and others, 2014) as part of a study to compare simulated flood elevations to those observed in 2010 (Zarriello and Bent, 2011). This model was calibrated with the selected high-water marks from the March 30, 2010, flood (Zarriello and Bent, 2011). The hydraulic model was updated with additional selected cross-section and hydraulic structure surveys in 2016 for use by the USGS in an ongoing (as of
2018) FEMA Risk Mapping, Assessment, and Planning (Risk MAP) program study for updating the FISs for PawcatuckWood Watershed.

\section{Creation of Flood-Inundation-Map Library}

The USGS has standardized the procedures for creating flood-inundation maps for flood-prone communities so that the process followed and products produced are similar across studies. Tasks specific to development of the flood maps for the lower Pawcatuck River include (1) modification of the Pawcatuck River hydraulic model being used by the USGS for an ongoing (as of 2018) FEMA Risk MAP program study for updating the FISs for Pawcatuck-Wood Watershed, (2) verification of energy-loss factors (roughness coefficients) in the stream channel and flood plain, (3) computation of water-surface profiles for the selected 1-ft stage intervals at the Pawcatuck River at Westerly streamgage using the U.S. Army Corps of Engineers (USACE) Hydrologic Engineering Center's River Analysis System (HEC-RAS) version 5.0.3 computer program (U.S. Army Corps of Engineers, 2016), (4) production of flood-inundation maps corresponding to each modeled flood profile using the USACE HEC-GeoRAS computer program (U.S. Army Corps of Engineers, 2009) and a geographic information system (GIS), and (5) preparation of the maps as shapefile polygons that depict the areal extent of flood inundation and as depth grids that provide the depth of floodwaters for display on a USGS flood-inundation mapping application.

\section{Computation of Water-Surface Profiles}

The water-surface profiles used to produce the 11 floodinundation maps in this study were computed by using HECRAS version 5.0.3 software (U.S. Army Corps of Engineers, 2016). HEC-RAS is a one-dimensional step-backwater model for simulation of water-surface profiles, and it includes options for computing steady-state (gradually varied) or unsteadystate flow.

\section{Hydrology}

The study reach includes the Pawcatuck River at Westerly streamgage, which has been in operation since November 1940 (fig. 1; table 1). The streamgage is about $0.1 \mathrm{mi}$ downstream from Stillman Avenue bridge, which is about $4.9 \mathrm{mi}$ downstream from the upstream end of the study reach and about $0.6 \mathrm{mi}$ upstream from the downstream end of the study reach. The river stage is measured every 15 minutes, is transmitted hourly via satellite, and is available on the USGS National Water Information System (NWIS) website (U.S. Geological Survey, 2017). River stage data from this 
Table 2. Peak-discharge estimates for selected annual exceedance probabilities at the U.S. Geological Survey Pawcatuck River at Westerly, Rhode Island, streamgage 01118500, using annual peak discharges for water years 1928, 1936, and 1941-2016.

[USGS, U.S. Geological Survey; $\mathrm{mi}^{2}$, square mile; $\mathrm{ft}^{3} / \mathrm{s}$, cubic foot per second; \%, percent; RI, Rhode Island]

\begin{tabular}{|c|c|c|c|c|c|c|c|c|c|c|}
\hline \multirow{2}{*}{$\begin{array}{l}\text { USGS streamgage } \\
\text { name and number }\end{array}$} & \multirow{2}{*}{$\begin{array}{c}\text { Drainage } \\
\text { area, } \\
\text { in } \mathrm{mi}^{2}\end{array}$} & \multicolumn{8}{|c|}{$\begin{array}{l}\text { Estimated peak discharge, in } \mathrm{ft}^{3} / \mathrm{s} \text {, for } \\
\text { annual exceedance probabilities }\end{array}$} & \multirow{2}{*}{$\begin{array}{c}\text { Peak flow, March } 30 \text {, } \\
\text { 2010, flood, in } \mathrm{ft}^{3} / \mathrm{s}\end{array}$} \\
\hline & & $50 \%^{1}$ & $20 \%$ & $10 \%$ & $4 \%$ & $2 \%$ & $1 \%$ & $0.5 \%$ & $0.2 \%$ & \\
\hline $\begin{array}{l}\text { Pawcatuck River at } \\
\text { Westerly, RI (01118500) }\end{array}$ & 295 & 2,390 & 3,400 & 4,220 & 5,400 & 6,410 & 7,540 & 8,730 & 10,500 & 10,800 \\
\hline
\end{tabular}

${ }^{1}$ Could not be weighted with the regional regression equation, since no equation was developed for Rhode Island (Zarriello and others, 2012).

streamgage are referenced to a local datum but can be converted to water-surface elevations referenced to the North American Vertical Datum of 1988 (NAVD 88) by subtracting $2.68 \mathrm{ft}$. Continuous records of streamflow are computed from a stage-discharge relation (rating curve) developed through concurrent stage and streamflow measurements collected since November 1940. The stage-discharge rating curve, 36.1, was used for this study.

The discharges input into the model simulations (table 3) were from stage-discharge relation rating curve 36.1 (active August 31, 2015 to October 6, 2016) and corresponded with the target stages. Stage-discharge relation rating curve 36.1 is the same as rating curve 36 from $3.90 \mathrm{ft}$ to $16.00 \mathrm{ft}$; rating curve 36 was in effect from March 14, 2010 to August 31, 2015. The upper end of the rating curve is based on high-flow measurements (U.S. Geological Survey, 2017) made during the late February through early April 2010 floods.

Only one tributary along the $5.5 \mathrm{mi}$ study reach, the Shunock River, has a drainage area greater than about $1 \mathrm{mi}^{2}$ at $16.5 \mathrm{mi}^{2}$ (fig. 1). The streamgage-derived discharges were adjusted to account for Shunock River inflows (table 3), and the study reach was split into two sections. The river-reach section associated with this study upstream from Shunock River has a starting drainage area of $271 \mathrm{mi}^{2}$ and an ending area of $275 \mathrm{mi}^{2}$. For this river-reach section, the adjusted flows used in the hydraulic model were calculated by using the drainage area at the downstream end of the section $\left(275 \mathrm{mi}^{2}\right)$ as a conservative measure. The river-reach section associated with this study downstream from the Shunock River has a starting drainage area of $292 \mathrm{mi}^{2}$ and an ending area of $297 \mathrm{mi}^{2}$. For this section, the flows used in the hydraulic model were the actual flows (table 3 ) at the Pawcatuck at Westerly streamgage (drainage area of $295 \mathrm{mi}^{2}$ ). The flows at the streamgage were used because of the small differences in the drainage areas of the upstream end, downstream end, and around the streamgage. Additionally, the flows at the streamgage are based on the stage-discharge rating curve developed by using actual flow measurements, which accurately represent flow conditions for this section of the study reach.
The adjusted flows for the river reach upstream from Shunock River were estimated by applying a drainage-area ratio method (Johnstone and Cross, 1949) to the discharges related to each of the 1-ft stage intervals from 6.0 to $16.0 \mathrm{ft}$ and the March 30, 2010, floodflow at the Pawcatuck River at Westerly streamgage. The upstream flows were calculated by using the following equation:

$$
Q_{u}=Q_{g}\left(\frac{D A_{u}}{D A_{g}}\right)^{e}
$$

where

$$
\begin{array}{ll}
Q_{u} & \begin{array}{l}
\text { is the streamflow at an ungaged location, in } \\
\text { cubic feet per second; }
\end{array} \\
Q_{g} & \begin{array}{l}
\text { is the streamflow at a gaged location, in } \\
\text { cubic feet per second; }
\end{array} \\
D A_{u} & \begin{array}{l}
\text { is the drainage area at an ungaged location, } \\
\text { in square miles; }
\end{array} \\
D A_{g} & \begin{array}{l}
\text { is the drainage area at a gaged location, in } \\
\text { square miles; and } \\
\text { is the exponent of the drainage-area-only } \\
\text { regional regression equations (table } \\
16 \text { of Zarriello and others, 2012) } \\
\text { for the appropriate AEP. }
\end{array}
\end{array}
$$

For the river-reach section upstream from Shunock River; $Q_{g}$ values for the Pawcatuck at Westerly streamgage are provided in table $3, D A_{u}$ is $275 \mathrm{mi}^{2}$, and $D A_{g}$ is $295 \mathrm{mi}^{2}$. The exponent $(e)$ was determined in the following three-step process: (1) the discharge at the Pawcatuck River at Westerly streamgage for each of the 1-ft stage intervals from 6.0 to $16.0 \mathrm{ft}$ and the March 30, 2010, floodflow (table 3) was determined from the stage-discharge rating, (2) each of these discharges was matched to the closest AEP floodflow in table 2, and (3) each AEP was matched to the exponent determined in a peak-flow study by Zarriello and others (2012, table 16). For example, at the Pawcatuck at Westerly streamgage, the discharge for a stage of $15.0 \mathrm{ft}$ is $10,200 \mathrm{ft}^{3} / \mathrm{s}$ (table 3), and this value is closest to the 0.2-percent AEP flow of 10,500 $\mathrm{ft}^{3} / \mathrm{s}$ (table 2), which relates to an exponent (e) of 0.76 for the 0.2-percent AEP in Zarriello and others (2012, table 16). 
Table 3. Estimated discharges for selected locations used in the hydraulic model of the lower Pawcatuck River in Westerly, Rhode Island, and Stonington and North Stonington, Connecticut, and the corresponding discharges, stages, and water-surface elevations at the U.S. Geological Survey Pawcatuck River at Westerly, Rhode Island, streamgage 01118500.

[Row shaded gray is the stage and discharge of the March 30, 2010, floodflow. USGS, U.S. Geological Survey; RI, Rhode Island; ft, foot; NAVD 88, North American Vertical Datum of $1988 ; \mathrm{ft}^{3} / \mathrm{s}$, cubic foot per second]

USGS Pawcatuck River at Westerly, RI, streamgage (01118500)

Estimated discharge applied to sections of river reach used in hydraulic model, in $\mathrm{ft}^{3} / \mathrm{s}$

\begin{tabular}{ccccc}
\hline $\begin{array}{c}\text { Stage of water-surface } \\
\text { profile, in ft referenced to } \\
\text { the gage datum }\end{array}$ & $\begin{array}{c}\text { Water-surface } \\
\text { elevation, in ft } \\
\text { above NAVD 88 }\end{array}$ & $\begin{array}{c}\text { 'Discharge, } \\
\text { in ft } \mathbf{s}^{\mathbf{s}}\end{array}$ & $\begin{array}{c}\text { At upstream end of river reach to } \\
\text { upstream from confluence with } \\
\text { Shunock River }\end{array}$ & $\begin{array}{c}\text { Downstream from confluence } \\
\text { with Shunock River to down- } \\
\text { stream end of river reach }\end{array}$ \\
\hline 6.00 & 3.32 & 1,270 & 1,200 & 1,270 \\
7.00 & 4.32 & 2,150 & 2,030 & 2,150 \\
8.00 & 5.32 & 2,980 & 2,820 & 2,980 \\
9.00 & 6.32 & 3,730 & 3,530 & 3,730 \\
10.00 & 7.32 & 4,520 & 4,270 & 4,520 \\
11.00 & 8.32 & 5,350 & 5,060 & 5,350 \\
12.00 & 9.32 & 6,220 & 5,890 & 6,220 \\
13.00 & 10.32 & 7,380 & 6,990 & 7,380 \\
14.00 & 11.32 & 8,750 & 8,290 & 8,750 \\
15.00 & 12.32 & 10,200 & 9,670 & 10,200 \\
16.00 & 13.32 & 11,900 & 11,300 & 11,900 \\
15.38 & & & & 10,200 \\
\hline
\end{tabular}

${ }^{1}$ Discharge is based on stage-discharge rating curve number 36.1 .

\section{Topographic and Bathymetric Data}

All topographic data used in this study are referenced vertically to NAVD 88 and horizontally to the North American Datum of 1983 (NAD 83). Cross-section elevation data were obtained for the Pawcatuck River corridor from a digital elevation model (DEM) that was derived from light detection and ranging (lidar) for the northeastern United States (National Oceanic and Atmospheric Administration, 2013a). The lidar data were collected as a part of the American Recovery and Reinvestment Act of 2009 (Public Law 111-5), coordinated and contracted through the USGS National Geospatial Technical Operations Center. The lidar data were collected from December 2010 through December 2011 and processed in 2012-13. The original lidar data have a vertical accuracy of $0.49 \mathrm{ft}$ for the bare-earth terrain land-cover category and were collected on a $3.28 \mathrm{ft}$ ground sample distance (National Oceanic and Atmospheric Administration, 2013b). By these criteria, the lidar data support production of 2-ft contours with an estimated vertical accuracy of $\pm 1 \mathrm{ft}$ (Snyder and others, 2014). The final DEM was resampled to a $6.5-\mathrm{ft}$ grid-cell size to decrease the GIS processing time. By using
HEC-GeoRAS, a set of procedures, tools, and utilities for processing geospatial data in Esri ArcGIS (Esri, 2016), elevation data were extracted from the DEM for 76 cross sections and subsequently input to the HEC-RAS model. Because lidar data cannot provide ground elevations below a stream's water surface for the model, channel cross sections were surveyed by USGS field crews during 2011 (Zarriello and others, 2014) and 2014-16 for the ongoing (as of 2018) FEMA Risk MAP program study for updating the FISs for Pawcatuck-Wood Watershed. A differential global positioning system (DGPS) with real-time kinematic (RTK) technology was used to derive horizontal locations and the elevation of the water surface at each surveyed cross section and hydraulic structure (bridges and dams) during 2011 and 2014-16. The USGS DGPS with RTK technology field surveys were checked periodically to known elevations at National Geodetic Survey (NGS) benchmark locations in Washington County, R.I., and New London County, Conn., during 2011 (Zarriello and Bent, 2011) and 2015-16 (Andrew Massey, U.S. Geological Survey, written commun., 2016). Generally, differences between the USGS and NGS benchmark elevations were less than $\pm 0.10 \mathrm{ft}$. 
Where possible, DEM-generated cross sections were made to coincide with the locations of the within-channel field-surveyed cross sections. In these cases, within-channel data were directly merged with the DEM data. For all other cross sections, the within-channel data were estimated by interpolation from the closest field-surveyed cross section.

\section{Hydraulic Model}

The hydraulic model for this study was developed by using HEC-RAS version 5.0.3 software (U.S. Army Corps of Engineers, 2016) and is based on the model used by the USGS for the ongoing (as of 2018) FEMA Risk MAP program study for updating the FISs for Pawcatuck-Wood Watershed. The hydraulic model was modified: (1) to reflect the removal of the White Rock dam during 2015-16, (2) with additional crosssectional surveys at the U.S. Route 1/Broad Street bridge and just upstream and downstream from that bridge, (3) with discharges for stages 6.0 to $16.0 \mathrm{ft}$ using the stage-discharge rating 36.1 at the Pawcatuck River at Westerly streamgage, and (4) with minor changes to $n$-values for calibration. Seven bridge structures have the potential to affect water-surface elevations during floods along the river. The bridge structures include five road crossings (Boom Bridge Road bridge is currently [2018] closed to traffic), one wooden farm bridge (Post Office Lane), and one railroad bridge (fig. 1 and table 4). Bridge-geometry data were obtained by USGS field crews during 2011 (Zarriello and others, 2014) and 2014-16, according to FEMA standards for the Risk MAP program (Federal Emergency Management Agency, 2011).

Hydraulic analyses require the estimation of energy losses that result from frictional resistance exerted by a channel on flow. These energy losses are quantified by the Manning's roughness coefficient ( $n$-value). Initial (precalibration) $n$-values were selected on the basis of field observations and high-resolution aerial photographs (Barnes, 1967) and refined during high-water mark calibration. Commercial and industrial land uses and medium- to high-density residential housing areas are present along the riparian corridor of the lower Pawcatuck River, along with sections that are primarily wooded with fairly dense vegetation. The channel $n$-values range from 0.030 to 0.045 because the channel is mainly sand and gravel with some cobbles interspersed. The $n$-values for the overbanks of the riparian corridor (floodplain) range from 0.055 to 0.12 depending on the openness of the section. Bankfull channel-top widths typically are between about 200 and $600 \mathrm{ft}$ wide but can be over 1,000 ft wide. As part of the calibration process, the initial $n$-values were varied by flow and adjusted until the differences between simulated and observed watersurface elevations at the streamgage and at high-water marks were minimized.

The HEC-RAS analysis was done using the steady-state flow computation option. Steady-state flow data consisted of flow regime, boundary conditions, and peak flows that produced water-surface elevations at the streamgage cross section that closely matched target water-surface elevations. These target elevations coincided with even 1-ft increments of stage, referenced to the local gage datum. Subcritical (tranquil) flow regime was assumed for the simulations. Normal depth, based on an estimated average streambed slope of $0.0001 \mathrm{ft} / \mathrm{ft}$ downstream from the downstream end of the reach (section used for average streambed slope calculation was from about 0.2 to 1.5 mi downstream from the Rt. 1/Broad St. bridge, which is downstream from the downstream end of the reach-500 ft downstream from the Rt. 1/Broad St. bridge), was used as the downstream boundary condition for the reach. The HEC-RAS model was calibrated to the stage-discharge relation (rating curve 36.1) at the Pawcatuck River at Westerly streamgage and to 10 flagged and surveyed HWMs from the water surface of the period of record peak flood of March 30, 2010 (Zarriello and Bent, 2011).

Table 4. Description of bridge crossings in the hydraulic model of the lower Pawcatuck River in Westerly, Rhode Island, and Stonington and North Stonington, Connecticut.

[ft, foot; Rt., route; Ave., Avenue; --, not applicable; U.S., United States]

\begin{tabular}{cllll}
\hline $\begin{array}{c}\text { River station, } \\
\text { in ft }\end{array}$ & Structure & \multicolumn{1}{c}{ Name } & \multicolumn{1}{c}{ Municipality } & \multicolumn{1}{c}{ Remarks } \\
\hline $37,199.66$ & Bridge & Post Office Lane & Westerly/North Stonington & Wooden bridge for farm equipment \\
$29,529.54$ & Bridge & Boom Bridge Road & Westerly/North Stonington & Closed to traffic until replaced \\
$17,902.12$ & Bridge & Bridge Road/White Rock Bridge Road & Westerly/Stonington & -- \\
$16,513.25$ & Bridge & State Rt. 78/Veterans Way & Westerly/Stonington & -- \\
$12,263.73$ & Bridge & Stillman Ave. & Westerly/Stonington & -- \\
$10,163.07$ & Bridge & Amtrak railroad & Westerly/Stonington & -- \\
$9,211.54$ & Bridge & U.S. Rt. 1/Broad Street & Westerly/Stonington & -- \\
\hline
\end{tabular}

1"River station" references the distance upstream to the downstream side of the structure from the most downstream point (starting point) in the hydraulic model. 
Table 5. Differences between 11 simulated water-surface elevations and stage elevations at 1-foot intervals from 6.00 to 16.00 feet for the U.S. Geological Survey Pawcatuck River at Westerly, Rhode Island, streamgage 01118500.

[ft, foot; NAVD 88, North American Vertical Datum of 1988]

\begin{tabular}{cccc}
\hline Stage, in ft & $\begin{array}{c}\text { Stage el- } \\
\text { evation, in ft } \\
\text { above NAVD } \\
\mathbf{8 8}\end{array}$ & $\begin{array}{c}\text { Simulated } \\
\text { water-surface } \\
\text { elevation, in ft } \\
\text { above } \\
\text { NAVD 88 }\end{array}$ & $\begin{array}{c}\text { Difference in } \\
\text { elevation, in ft }\end{array}$ \\
\hline 6.00 & 3.32 & 3.05 & 0.27 \\
7.00 & 4.32 & 4.45 & -0.13 \\
8.00 & 5.32 & 5.52 & -0.20 \\
9.00 & 6.32 & 6.39 & -0.07 \\
10.00 & 7.32 & 7.23 & 0.09 \\
11.00 & 8.32 & 8.06 & 0.26 \\
12.00 & 9.32 & 8.88 & 0.44 \\
13.00 & 10.32 & 10.46 & -0.14 \\
14.00 & 11.32 & 11.46 & -0.14 \\
15.00 & 12.32 & 12.18 & 0.14 \\
16.00 & 13.32 & 13.81 & -0.49 \\
\hline
\end{tabular}

Differences between the 11 stages of the stage-discharge relation (rating curve 36.1; NAVD 88 stages 3.32 to $13.32 \mathrm{ft}$ ) and the simulated water-surface elevations ranged from -0.49 to $+0.44 \mathrm{ft}$ (table 5). The average and median differences between the 11 stages and simulated water-surface elevations were 0.00 and $-0.07 \mathrm{ft}$, respectively. Absolute differences were less than $0.5 \mathrm{ft}$ for all of the 11 stages.

Differences between surveyed and simulated water-surface elevations of 10 selected HWMs in the study reach for the March 30, 2010 flood ranged from -1.06 to $2.10 \mathrm{ft}$ (table 6). The average and median differences between surveyed and simulated water-surface elevations for the $10 \mathrm{HWMs}$ were 0.15 and $0.05 \mathrm{ft}$, respectively. Absolute differences were less than $0.5 \mathrm{ft}$ for 6 of the $10 \mathrm{HWMs}$, between 0.5 to $1.0 \mathrm{ft}$ for 2 of the $10 \mathrm{HWMs}$, and greater than $1 \mathrm{ft}$ for 2 of the $10 \mathrm{HWMs}$. Field crews can sometimes collect a HWM that is lower than the peak water-surface elevation of a flood, as more than one line of marks can be left by debris, seeds, and mud as floodwaters recede (Feaster and Koenig, 2017). This is likely the case with USGS-100, as it has a simulated water-surface elevation $2.10 \mathrm{ft}$ higher than the surveyed HWM elevations, and as the model is well calibrated to another nearby HWM (USGS-99). Overall, the results demonstrate that the model is capable of simulating reasonably accurate water levels over a wide range of flows in the lower Pawcatuck River reach.

\section{Development of Water-Surface Profiles}

The calibrated hydraulic model was used to generate water-surface profiles for 11 stages at 1-ft intervals between $6.0 \mathrm{ft}$ and $16.0 \mathrm{ft}$ as referenced to the local datum of the Pawcatuck River at Westerly streamgage (01118500; table 7). These stages correspond to elevations of $3.32 \mathrm{ft}$ and $13.32 \mathrm{ft}$, NAVD 88, respectively. Discharges corresponding to the various stages were obtained from the stage-discharge relation (rating curve 36.1) for the Pawcatuck River at Westerly streamgage (table 3). The mapped stages were selected because the NWS AHPS's flood category "action stage" is $6.0 \mathrm{ft}$ (National Weather Service, 2017 and because the stage of $16.0 \mathrm{ft}$ is higher than the peak of the March 30, 2010, flood and is the maximum stage of the stage-discharge rating curve 36.1 . The stage of $16.0 \mathrm{ft}$ is $5.0 \mathrm{ft}$ higher than the NWS AHPS's flood category "major flood stage" of $11.0 \mathrm{ft}$ (National Weather Service, 2017).

\section{Flood-Inundation Maps}

Flood-inundation maps were created in a GIS for the 11 water-surface profiles by combining the profiles and DEM data. The maps depict the flood-inundation extent (flood-plain boundaries) of flood stages from 6.0 to $16.0 \mathrm{ft}$ (gage datum) at the Pawcatuck River at Westerly streamgage. The flood map corresponding to the simulated water-surface profile at a stage of $15.0 \mathrm{ft}$ is presented in figure 2; the stage of this map is the closest to the March 30, 2010, flood stage of $15.38 \mathrm{ft}$. The water-surface elevations of the most downstream section of the lower Pawcatuck River study reach (about the last $0.7 \mathrm{mi}$ of the reach; fig. 1) from downstream from the Stillman Avenue bridge to the downstream end of the reach (about $500 \mathrm{ft}$ downstream from the U.S. Route 1/Broad Street bridge) could be affected by tidal backwater from high tides coming up the Pawcatuck River, as discussed previously in the "Study Area Description" section. The flood-inundation maps depict only riverine flooding and do not depict any tidal backwater or coastal storm surge that could occur in the lower part of the river reach.

The DEM data were derived from the same lidar data described previously in the section "Topographic and Bathymetric Data" and therefore have an estimated vertical accuracy of $\pm 1 \mathrm{ft}$. Estimated flood-inundation boundaries for each simulated profile were developed with HEC-GeoRAS software (U.S. Army Corps of Engineers, 2009), which enables the preparation of geometric data for import into HEC-RAS software and processes simulation results exported from HEC-RAS (U.S. Army Corps of Engineers, 2016). Shapefile polygons and depth grids of the inundated areas for each profile were modified, as required, in the ArcMap application of ArcGIS (Esri, 2016) to ensure a hydraulically reasonable transition of the flood boundaries between modeled cross sections.

The flood-inundation areas are overlaid on high-resolution, geospatially referenced aerial photographs of the study area (fig. 2). Any inundated areas that were detached from 
Table 6. Differences between the hydraulic model simulated water-surface elevations for the March 30,2010 , floodflows and the surveyed high-water mark elevations on the lower Pawcatuck River in Westerly, Rhode Island, and Stonington and North Stonington, Connecticut.

[HWM, high-water mark; NAVD 88, North American Vertical Datum of 1988; USGS, U.S. Geological Survey; Rd., Road; St., Street; Rt., Route; U.S., United States]

\begin{tabular}{|c|c|c|c|c|c|c|}
\hline \multirow{2}{*}{$\begin{array}{l}\text { River } \\
\text { station, } \\
\text { in feet }^{1}\end{array}$} & \multirow{2}{*}{$\begin{array}{c}\text { HWM } \\
\text { identification } \\
\text { number }\end{array}$} & \multirow{2}{*}{ HWM location } & \multirow{2}{*}{$\begin{array}{l}\text { HWM } \\
\text { rating }\end{array}$} & \multicolumn{2}{|c|}{$\begin{array}{l}\text { Water-surface } \\
\text { elevation, in feet } \\
\text { above NAVD } 88\end{array}$} & \multirow{2}{*}{$\begin{array}{c}\text { Difference } \\
\text { in elevation, } \\
\text { in feet }\end{array}$} \\
\hline & & & & Model & $\mathrm{HWM}^{2}$ & \\
\hline $29,626.93$ & USGS-103 & Upstream side of Boom Bridge Rd. bridge & Good & 29.45 & 29.54 & -0.09 \\
\hline $29,495.33$ & USGS-104 & Downstream side of Boom Bridge Rd. bridge & Good & 29.67 & 29.73 & -0.06 \\
\hline $17,953.18$ & USGS-102 & Upstream side of Bridge Rd./White Rock Bridge Rd. bridge & Excellent & 19.03 & 18.61 & 0.42 \\
\hline $17,816.35$ & USGS-101 & Downstream side of Bridge Rd./White Rock Bridge Rd. bridge & Good & 18.51 & 18.36 & 0.15 \\
\hline $16,580.26$ & USGS-100 & Upstream side of State Rt. 78 bridge & Good & 17.43 & 15.33 & 2.10 \\
\hline $16,376.61$ & USGS-99 & Downstream side of State Rt. 78 bridge & Good & 16.29 & 16.58 & -0.29 \\
\hline $12,910.87$ & USGS-97 & Upstream side of 63 Canal St. building & Fair & 14.26 & 14.76 & -0.50 \\
\hline $12,191.28$ & USGS-98 & Downstream side of 63 Canal St. building & Good & 12.92 & 13.98 & -1.06 \\
\hline $9,256.12$ & USGS-96 & Upstream side of U.S. Rt. 1/Broad St. bridge & Fair & 9.20 & 9.03 & 0.17 \\
\hline $9,154.00$ & USGS-95 & Downstream side of U.S. Rt. 1/Broad St. bridge & Poor & 7.29 & 6.59 & 0.70 \\
\hline
\end{tabular}

1"River station" references the distance upstream to the downstream side of the structure from the most downstream point (starting point) in the hydraulic model.

${ }^{2} \mathrm{HWM}$ information from Zarriello and Bent (2011).

${ }^{3}$ Rating of HWMs is from Koenig and others (2016, table 2)

the main channel were examined to identify subsurface connections with the main river, such as through culverts under roadways. Where such connections existed, the mapped inundated areas were retained in their respective flood maps; otherwise, the erroneously delineated parts of the flood extent were deleted. Bridge surfaces are shown as not inundated up to the lowest flood stage that either intersects the lowest structural chord of the bridge or completely inundates one or both approaches to the bridge. Where the lowest flood stage either intersects the lowest structural chord of the bridge or completely inundates one or both approaches to the bridge, the bridge surface is depicted as being inundated. A shaded building should not be interpreted to mean that the structure is completely submerged, but rather that bare-earth surfaces in the vicinity of the building are inundated, and the water depth (as indicated in the mapping application by hovering the cursor over the inundated area) near the building would be an estimate of the water level inside the structure, unless flood-proofing measures had been implemented. Estimates of water depth can be obtained from the depth-grid data that are included with the presentation of the flood maps on an interactive USGS mapping application described in the "Flood-Inundation Map Delivery" section.

\section{Flood-Inundation Map Delivery}

The USGS Flood Inundation Mapping Science website at http://water.usgs.gov/osw/flood_inundation makes USGS flood-inundation study information available to the public through a mapping application that presents map libraries and provides detailed information on flood extents and depths for modeled sites in the United States. The mapping application helps users produce customized flood-inundation maps from the map library through a print-on-demand feature that allows the user to zoom to the area of interest, choose the desired stage, and print only that part of the map (for example, fig. 2). The flood-inundation maps are displayed in enough detail that preparations for flooding and decisions for emergency response can be made efficiently.

The mapping application provides a link to the USGS NWIS website (U.S. Geological Survey, 2017), which presents the current (real-time) stage and streamflow at the Pawcatuck River at Westerly streamgage (01118500), to which the inundation maps are referenced. A second link connects to the NWS AHPS website for the streamgage (WSTR1; National Weather Service, 2017) so that the user can obtain applicable information on the forecasted stage at the streamgage. 
Table 7. Stage, discharge, and approximate annual exceedance probability at the U.S. Geological Survey Pawcatuck River at Westerly, Rhode Island, streamgage 01118500 for profiles mapped on the lower Pawcatuck River in Westerly, Rhode Island, and Stonington and North Stonington, Connecticut.

[ft, foot; NAVD 88, North American Vertical Datum of 1988; $\mathrm{ft}^{3} / \mathrm{s}$, cubic foot per second; NA, not applicable]

\begin{tabular}{ccccc}
\hline $\begin{array}{c}\text { Grid } \\
\text { identification' }\end{array}$ & $\begin{array}{c}\text { Stage, } \\
\text { in ft }\end{array}$ & $\begin{array}{c}\text { Stage } \\
\text { elevation, } \\
\text { in ft } \\
\text { above } \\
\text { NAVD 88 }\end{array}$ & $\begin{array}{c}\text { Closest } \\
\text { Discharge, } \\
\text { in ft }{ }^{3} / \mathbf{s}\end{array}$ & $\begin{array}{c}\text { cloodflow's } \\
\text { annual } \\
\text { exceedance } \\
\text { probability, } \\
\text { in percent }\end{array}$ \\
\hline PawcatucRI_01 & 6.00 & 3.32 & 1,270 & NA \\
PawcatucRI_02 & 7.00 & 4.32 & 2,150 & 50 \\
PawcatucRI_03 & 8.00 & 5.32 & 2,980 & NA \\
PawcatucRI_04 & 9.00 & 6.32 & 3,730 & 20 \\
PawcatucRI_05 & 10.00 & 7.32 & 4,520 & 10 \\
PawcatucRI_06 & 11.00 & 8.32 & 5,350 & 4 \\
PawcatucRI_07 & 12.00 & 9.32 & 6,220 & 2 \\
PawcatucRI_08 & 13.00 & 10.32 & 7,380 & 1 \\
PawcatucRI_09 & 14.00 & 11.32 & 8,750 & 0.5 \\
${ }^{3}$ PawcatucRI_10 & 15.00 & 12.32 & 10,200 & 0.2 \\
PawcatucRI_11 & 16.00 & 13.32 & 11,900 & NA \\
\hline
\end{tabular}

${ }^{1}$ Grid identification is the shapefile and depth map file names for each of the 11 river stages for the Pawcatuck River study reach provided in Bent and Lombard (2018).

${ }^{2}$ See table 2 for the estimated peak-discharges for the selected annual exceedance probabilities.

${ }^{3}$ PawcatucRI_10 map has the closest stage value to the March 30, 2010, peak flow stage, and thus most closely approximates that flood.

All GIS files presented on the USGS Flood Inundation Mapping Science website and metadata associated with each of the files are available as a USGS data release (Bent and Lombard, 2018).

\section{Disclaimer for Flood-Inundation Maps}

The flood-inundation maps should not be used for navigation, regulatory, permitting, or other legal purposes. The USGS provides these maps "as-is" for a quick reference, emergency planning tool but assumes no legal liability or responsibility resulting from the use of this information.

\section{Uncertainties and Limitations Regarding Use of Flood-Inundation Maps}

Although the flood-inundation maps represent the boundaries of inundated areas with a distinct line, some uncertainty is associated with these maps. There are uncertainties associated with the hydrology, the model, the observed water surfaces, and the mapping. The flood boundaries shown were estimated on the basis of flood stages and streamflows at the Pawcatuck River at Westerly streamgage. There are errors associated with the stage-discharge rating curves used to estimate flow at the streamgage because the rating curve is smoothed through the streamflow measurements and the concurrent stage. Estimates of flow are computed upstream from the streamgage by using the estimates of flows at the streamgage and then adjusting them for the change in drainage area from the streamgage to the new location. Meteorological factors, such as the timing and distribution of precipitation, may cause actual streamflows along the modeled reach to vary from those assumed during a flood, which may lead to variations in the water-surface elevations and inundation boundaries shown on the maps.

Water-surface elevations along the stream reaches were estimated by using steady-state hydraulic modeling, assuming unobstructed flow, and using streamflows and hydrologic conditions anticipated at the streamgage. The hydraulic model reflects the land-cover characteristics and any bridge, dam, levee, or other hydraulic structures existing as of September 2017. The HEC-RAS model is a one-dimensional hydraulic model and, as such, cannot always capture everything that occurs during a flood. Additional areas may be flooded as a result of unanticipated conditions, such as changes in the streambed elevation or roughness, backwater into major tributaries along a main-stem river, or backwater from localized debris. HEC-RAS models are more accurate when they are calibrated to flows from streamgages and to HWMs collected after flooding events. The HWMs collected in the field are from actual events and are given a rating from poor $( \pm 0.4 \mathrm{ft}$ perceived difference between the field-identified elevation and the actual water-surface elevation during the event) to excellent ( $\pm 0.05 \mathrm{ft}$ ) (table 2 of Koenig and others, 2016) at the time they are collected (table 6). Ratings of the HWMs often reflect the quality of the HWM itself and do not always take into account when the HWM occurred during a storm, as some very clear HWMs can occur on the recession of a flood, when the stage holds steady for a time. Thus, the models are as good as the data to which they are calibrated.

The accuracy of the floodwater extent portrayed on these maps will vary with the accuracy of the DEM used to simulate the land surface. Thus, the mapping of the flood boundaries and the depths of the inundated areas on the maps have some uncertainty. Additionally, the flood-inundation maps depict only riverine flooding and do not depict any tidal backwater or coastal storm surge that could occur in the lower part of the river reach during a flood.

If this series of flood-inundation maps will be used in conjunction with NWS river forecasts, the user should be aware of additional uncertainties that may be inherent or factored into NWS forecast procedures. The NWS uses forecast models to estimate the quantity and timing of water flowing through selected stream reaches in the United States. These 
forecast models (1) estimate the amount of runoff generated by precipitation and snowmelt, (2) simulate the movement of floodwater as it proceeds downstream, and (3) predict the flow and stage (and water-surface elevation) for the stream at a given location (NWS AHPS forecast point; National Weather Service, undated) throughout the forecast period (typically every 6 hours and 3 to 5 days out in many locations).

\section{Summary}

A series of 11 digital flood-inundation maps was developed by the U.S. Geological Survey (USGS), in cooperation with the Town of Westerly, Rhode Island, and the Rhode Island Office of Housing and Community Development, for the lower Pawcatuck River in Westerly, Rhode Island, and Stonington and North Stonington, Connecticut. The maps cover a reach about 5.5 miles long from downstream from the Ashaway River inflow at the Hopkinton and Westerly, Rhode Island, and North Stonington, Connecticut, border to about 500 feet (ft) downstream from the U.S. Route 1/Broad Street bridge in Westerly, Rhode Island, and Stonington, Connecticut. The maps were developed by using U.S. Army Corps of Engineers Hydrologic Engineering Center's River Analysis System (HEC-RAS) and HEC-GeoRAS software to compute water-surface profiles and to delineate estimated flood-inundation areas and depths of flooding for selected stream stages.

Flood profiles were computed for this reach of the lower Pawcatuck River by means of a one-dimensional step-backwater HEC-RAS hydraulic model created and calibrated by the USGS in 2016 for an ongoing (as of 2018) Federal Emergency Management Agency Risk Mapping, Assessment, and Planning program study for updating the Flood Insurance Studies for Pawcatuck-Wood Watershed. The model was updated to reflect the removal of the White Rock dam during 2015-16. The hydraulic model was calibrated to the stage-discharge relation (rating curve 36.1) at the USGS Pawcatuck River at Westerly, R.I., streamgage (01118500) and to the peak watersurface elevations (high-water marks) along the 5.5-mile reach from the March 30, 2010, flood. The March 30, 2010, peak flow at the Pawcatuck River at Westerly streamgage was slightly greater than the estimated 0.2 -percent annual exceedance probability floodflow.

The hydraulic model was used to simulate 11 water-surface profiles for flood stages at $1-\mathrm{ft}$ intervals referenced to the gage datum and ranging from $6.0 \mathrm{ft}(3.32 \mathrm{ft}$, North American Vertical Datum of 1988), which is the National Weather Service (NWS) Advanced Hydrologic Prediction Service (AHPS) flood category "action stage," to $16.0 \mathrm{ft}(13.32 \mathrm{ft}$, North American Vertical Datum of 1988), which is the maximum rated stage at the streamgage and exceeds the maximum recorded stage (15.38 ft, March 30, 2010) and the NWS AHPS flood category "major flood stage" (11.0 ft). The 11 simulated water-surface profiles do not account for any effect from tidal backwater or coastal storm surge in the lower part of the river reach that could occur during a flood. The water-surface profiles depict riverine flooding only, such as the late February through early April 2010 flooding.

The 11 water-surface profiles were then combined with a geographic information system digital elevation model derived from light detection and ranging (lidar) data to delineate estimated flood-inundation areas as shapefile polygons and depth grids for each profile. These flood-inundation polygons were overlaid on high-resolution, georeferenced aerial photographs of the study area. The flood maps are available through a mapping application that can be accessed on the USGS Flood Inundation Mapping Science website (http://water.usgs.gov/ osw/flood_inundation). Within this mapping application, users can click within the flood-inundation areas for a general indication of depth of water at any point on the maps. These maps, in conjunction with the real-time stage data for the USGS Pawcatuck River at Westerly, R.I., streamgage (01118500) from the National Water Information System and forecasted stage data from the NWS AHPS (WSTR1), will help to guide the general public in taking individual safety precautions and will provide emergency management personnel with a tool to efficiently manage emergency flood operations and postflood recovery efforts. The flood-inundation maps are nonregulatory but provide Federal, State, and local agencies and the public with estimates of the potential extent of flooding during flood events.

\section{References Cited}

Barnes, H.H., Jr., 1967, Roughness characteristics of natural channels: U.S. Geological Survey Water-Supply Paper 1849, 219 p., accessed August 24, 2018, at https://pubs.usgs.gov/wsp/wsp_1849/html/pdf.html.

Bent, G.C., and Lombard, P.J., 2018, Flood-inundation grids and shapefiles for the lower Pawcatuck River in Westerly, Rhode Island, and North Stonington and Stonington, Connecticut: U.S. Geological Survey data release, https://doi.org/10.5066/F7610Z80.

England, J.F., Jr., Cohn, T.A., Faber, B.A., Stedinger, J.R., Thomas, W.O., Jr., Veilleux, A.G., Kiang, J.E., and Mason, R.R., Jr., 2018, Guidelines for determining flood flow frequency-Bulletin 17C: U.S. Geological Survey Techniques and Methods, book 4, chap. B5, 148 p., accessed March 30, 2018, at https://doi.org/10.3133/tm4B5.

Esri, 2016, ArcGIS: Esri software, accessed August 11, 2016, at http://www.esri.com/software/arcgis/.

Feaster, T.D., and Koenig, T.A, 2017, Field manual for identifying and preserving high-water mark data: U.S. Geological Survey Open-File Report 2017-1105, 67 p., accessed October 31, 2017, at https://doi.org/10.3133/ofr20171105. 
Federal Emergency Management Agency [FEMA], 2011, Guidelines and standards for flood risk analysis and mapping, Appendix M-Data capture standards: Federal Emergency Management Agency, final, August 2011, 99 p., accessed August 24, 2018, at https://www.fema.gov/ media-library-data/1384807003272-423d7d8c94ca74f21c0a401160553e7f/Guidelines_and_Standards_for_Flood_ Risk_Analysis_and_Mapping_Appendix_M_-_Guidance_for_Technical_and_Administrative_Support_Data_ (Aug_2011).pdf.

Federal Emergency Management Agency [FEMA], 2013a; Flood Insurance Study - New London County, Connecticut (all jurisdictions), revised August 5, 2013, flood insurance study number 09011CV001B: Federal Emergency Management Agency, 3 v., 158 p., 162 flood profiles.

Federal Emergency Management Agency [FEMA], 2013b; Flood Insurance Study - Washington County, Rhode Island (all jurisdictions), revised October 16, 2013, flood insurance study number 44009CV001B: Federal Emergency Management Agency, 2 v., 84 p., 54 flood profiles.

Hallenbeck, B., 2010, Economy forces up river's decision to close; flooding didn't help: The Day Local News, New London, Connecticut, accessed May 30, 2018 at https://www.theday.com/article/20100414/ NWS01/100419901.

Johnstone, Don, and Cross, W.P., 1949, Elements of applied hydrology: New York, Ronald Press Co., 276 p.

Koenig, T.A., Bruce, J.L., O’Connor, J.E., McGee, B.D., Holmes, R.R., Jr., Hollins, R., Forbes, B.T., Kohn, M.S., Schellekens, M.F., Martin, Z.W., and Peppler, M.C., 2016, Identifying and preserving high-water mark data: U.S. Geological Survey Techniques and Methods, book 3, chap. A24, 47 p., at http://dx.doi.org/10.3133/tm3A24.

National Oceanic and Atmospheric Administration, 2010, National Centers for Environmental Information, Westerly State Airport, Westerly, RI, Global Historical Climatology Network-Daily (GHCND) number-USW00014794: National Oceanic and Atmospheric Administration precipitation data, accessed September 5, 2017, at https://www.ncdc.noaa.gov/cdo-web/datasets/GHCND/stations/GHCND:USW00014794/detail.

National Oceanic and Atmospheric Administration, 2013a, 2011 U.S. Geological Survey topographic LiDAR: LiDAR for the North East: National Oceanic and Atmospheric Administration metadata, accessed May 3, 2017, at https://coast.noaa.gov/dataservices/Metadata/ TransformMetadata?u=https://coast.noaa.gov/data/Documents/Metadata/Lidar/harvest/ne2011_usgs_lftne_m2524_ metadata. $\mathrm{xml} \& \mathrm{f}=\mathrm{html}$.
National Oceanic and Atmospheric Administration, 2013b, State of Rhode Island (classified LAS): LIDAR for the north east-ARRA and LiDAR for the north east part II: National Oceanic and Atmospheric Administration metadata, accessed May 3, 2017, at https://coast.noaa.gov/htdata/ lidar1_z/geoid12a/data/2524/supplemental/ne2011_usgs_ lftneRI.xml.

National Weather Service, [undated], A brief overview of the NWS precipitation and river forecasting and the river forecast on the AHPS hydrograph: National Oceanic and Atmospheric Administration, 1 p., accessed October 7, 2017, at http://water.weather.gov/ahps/pcpn_and_river_forecasting. pdf.

National Weather Service, 2017, Advanced Hydrologic Prediction Service, Pawcatuck River at Westerly, Rhode Island: National Weather Service website, accessed September 5, 2017, at http://water.weather.gov/ahps2/hydrograph. php?wfo=box\&gage=wstr 1 .

Rhode Island Coastal Resources Management Council, 2017, RI shoreline change special area management plan: STORMTOOLS: Rhode Island Shoreline Change Special Area Management Plan web page, accessed May 1, 2017, at http://www.beachsamp.org/stormtools/.

Snyder, G.I., Sugarbaker, L.J., Jason, A.L., and Maune, D.F., 2014, National requirements for enhanced elevation data: U.S. Geological Survey Open-File Report 2013-1237, 371 p., accessed October 16, 2014, at http://dx.doi.org/10.3133/ ofr20131237.

U.S. Army Corps of Engineers, Hydrologic Engineering Center, 2009, HEC-GeoRAS, GIS tools for support of HECRAS using ArcGIS, user's manual (ver. 4.2): U.S. Army Corps of Engineers CPD-83 [variously paged].

U.S. Army Corps of Engineers, Hydrologic Engineering Center, 2016, HEC-RAS River Analysis System, hydraulic reference manual (ver. 5.0): U.S. Army Corps of Engineers CPD-69 [variously paged].

U.S. Census Bureau, 2016, Quickfacts: U.S. Census Bureau, population data, accessed August 27, 2017, at https://www.census.gov/quickfacts/fact/table/US/ PST045216.

U.S. Geological Survey, 2017, USGS 01118500 Pawcatuck River at Westerly, RI in USGS water data for the Nation: U.S. Geological Survey National Water Information System database, accessed May 9, 2017, at https://waterdata.usgs.gov/nwis/inventory/?site no $=01118500$ \&agency_cd $=$ USGS. 
Zarriello, P.J., Ahearn, E.A., and Levin, S.B., 2012, Magnitude of flood flows for selected annual exceedance probabilities in Rhode Island, through 2010: U.S. Geological Survey Scientific Investigations Report 2012-5109, 93 p. [Also available at http://pubs.usgs.gov/sir/2012/5109/.]

Zarriello, P.J., and Bent, G.C., 2011, Elevation of the MarchApril 2010 flood high water in selected river reaches in Rhode Island: U.S. Geological Survey Open-File Report 2011-1029, 34 p. [Also available at http://pubs.usgs.gov/ ofr/2011/1029/.]
Zarriello, P.J., Straub, D.E., and Smith, T.E., 2014, Simulated and observed 2010 floodwater elevations in the Pawcatuck and Wood Rivers, Rhode Island: U.S. Geological Survey Scientific Investigations Report 2013-5193, 24 p., accessed May 23, 2017 at http://dx.doi.org/10.3133/sir20135193. 
For more information about this report, contact: Director, New England Water Science Center U.S. Geological Survey

10 Bearfoot Road

Northborough, MA 01532

dc_nweng@usgs.gov

or visit our website at

https://newengland.water.usgs.gov

Publishing support provided by the Pembroke Publishing Service Center 
